\title{
Learning via Television Cartoon
}

\author{
Normaliza Abd Rahim ${ }^{1}$, Hazlina Abdul Halim ${ }^{1} \&$ Roslina Mamat ${ }^{1}$ \\ ${ }^{1}$ Faculty of Modern Languages and Communication, Universiti Putra Malaysia, Serdang, 43400 Selangor, \\ Malaysia \\ Correspondence: Normaliza Abd Rahim, Faculty of Modern Languages and Communication, Universiti Putra \\ Malaysia, Serdang, 43400 Selangor, Malaysia. E-mail: drnormaliza@gmail.com
}

Received: March 24, $2014 \quad$ Accepted: June 11,2014 Online Published: July 11, 2014
doi:10.5539/ass.v10n15p8
URL: http://dx.doi.org/10.5539/ass.v10n15p8

\begin{abstract}
Cartoons have been a favorite among children, teenagers and adults. Cartoons began with paper drawing and have evolved to the highest technology of dissemination in the form of movies; apart from that, cartoons have become a teaching tool for second language learners. The objectives of the study were to identify and discuss the characters, storyline and moral values in a Malay cartoon. The cartoon used in this study was Upin and Ipin. The samples consist of ten subjects from a Malay language proficiency class at one of the universities in Korea. The subjects viewed 8 episodes of Upin and Ipin for 1 hour a week for a total of 8 weeks. The subjects were interviewed based on their views about the cartoon. The results of the study revealed that the subjects managed to identify all of the characters in the cartoon. The subjects also understood the storylines in six episodes of the cartoon. Moreover, the results revealed that the moral values for each episode involved respect, hardworking, caring, loving and others. This study implicates educators to consider cartoons as a teaching tool in foreign language learning. It is hoped that a future study will focus on cartoons when learning to write short stories among Malay language learners.
\end{abstract}

Keywords: cartoon, Malay language, characters, storyline, moral values

\section{Introduction}

Cartoons have been a favorite for people of all ages. A person will be happy just by watching cartoons on television or by reading cartoons as in comics. Cartoon allows one to release one's stress. The term 'cartoon' is used as a term to include stand alone illustrations, captioned or non-captioned, television or movie cartoons and short comic strip formats, which makes a potentially valuable contribution. Visually, the impact is immediate, and all students, irrespective of age or background, are able to respond in some way to the educational point being made. The value of humor in the teaching and learning process is reasonably well recognized, particularly in the establishment of a positive learning environment (Sever \& Ungar, 1997) as well as in the relationship between teachers and students (Pollack \& Freda, 1999).

However, today, educators are beginning to view cartoons as potential educational tools, as a way to increase and arouse students' interest in any academic subjects (Cleaver, 2008), as well as to improve students' academic literacy (Tilley, 2008). Cartoons have particular attraction among school-age children (Wright \& Sherman, 2006). Cox (1999) mentions that teachers place emphasis on students' use of the language as soon as they start learning the target language. Dedicated and good teachers have devoted much time and expertise to ways of producing appropriate situations for language use. In the conventional way of teaching and learning, many students, sit in class and work on exercises given by the teachers; many of the students find the activities to be boring. Teachers have a different perspective toward this matter; some just ignore the issue whereas others try to find more interesting ways to teach students. When teaching a foreign language, it should be contextualized, as explained by Brewster et al., (2003). Contextualization is the incorporation of materials to be learned into an identifiable and meaningful context. Apart from this, the use of personalization, in which students are involved in learning, and the usage of the language in real life can be achieved using a variety of techniques, such as video analysis, viewing filmstrips, role-plays, regular letter, and use of single cartoons and cartoon strips (Brewster et al., 2003). Harmer (1992) agrees that it is essential to create a stimulating and realistic environment when learning a foreign language. A pleasant atmosphere should be established in learning (Rahim et al., 2011). Moreover, the materials presented must be varied and become something to which students can readily identify (Rahim \& Roslan, 2012). 
Furthermore, according to Keogh \& Naylor (1999), concept cartoons are learning and teaching tools that are used primarily in science education in order to explore scientific concepts. Science has been a difficult subject, particularly making sure that the students have a clear understanding of the concept. Therefore, with the help of cartoons, there has been a major change in teaching and learning. Cartoons share some common traits with those used in comic strips; however, rather than being designed for humor, they aim to present to students the opportunity to interpret and understand the concepts (Keogh \& Naylor, 1999). Concept cartoons include a pictorial representation of characters in settings familiar to students, along with the use of written language in speech bubbles (Keogh \& Naylor, 1999; Kinchin, 2004). The familiar settings and characters give relevance to the ideas of the message that is being delivered. Thus, it is important that alternative conceptions, statements or questions pertaining to a central idea are presented within the cartoon in order to make teaching and learning a success (Kinchin, 2004). The use of speech bubbles and written language are also important for making the learning environment fun and interesting. Due to the characters' dialogue in the speech bubbles, students have the freedom to choose whether to agree or disagree with the views expressed by the characters without feeling threatened about publicly expressing their own opinion (Kinchin, 2004). Concept cartoons are primarily intended to act as an interesting teaching and learning tool; they help to arouse students interest, yet, they have also been proven to work effectively as a cognitive and affective assessment strategy (Keogh \& Naylor, 1999; Kinchin, 2004).

Cartoons are particularly useful because they are stimulating, varied and often humorous; they are also a major attraction toward learners in a difficult learning environment. Comprehension of the language is facilitated by a pictorial situation. Students are often reading cartoons in their own language or in a second language and thus, they are able to identify and understand easily with this medium. Reading cartoons in second language learning would motivate, enhance and increase the vocabulary in the target language. Nunan (1999) states that materials are essential for enhancing second language learning. Normaliza Abd Rahim \& Nik Ismail Harun (2011) agreed with Nunan (1999), stating that learning should come with motivation. Hence, learning should be fun and entertaining (Rahim, 2011; Rahim \& Roslan, 2012). Tanner \& Green (2002) research and observe that many materials for EFL teaching using communicative approach do not provide enough variety of idiom, colloquialism, and slang, which are part of everyday conversation. Cartoons are a means by which students can simultaneously widen and increase their vocabulary, and also improve their knowledge of the syntax, grammar and semantics of the language (Tanner \& Green, 2002). Besides having cartoons in second language learning, it has also been used in other subjects as a medium of learning. A study by Cho (2012) with both students and teachers reported positive results from using cartoons in a mathematics classroom. The results revealed that students became more open as time progressed and thus, it was possible to see their mathematical insights. The subjects did not enjoy easy cartoon activities, but rather asked for challenging ones. Their frustration at difficult-to-understand activities portrays the importance of carefully matching cartoon activities to student abilities and hence, it showed their enthusiasm toward learning. The results of the study by Cho (2012) revealed that when cartoon activities have appropriate levels of difficulty and are clearly understandable, students' intrinsic motivation and interest increased, whereas mathematics anxiety decreased. The teacher reported that students gave up less easily, participated more readily, were full of enthusiasm and were more focused in classes with cartoon activities. The results of the study also revealed that mathematics instruction with cartoon activities revealed to the students that they can enjoy learning mathematics, mathematics can be fun, and they do have the ability to be successful in mathematics. Thus, the use of cartoon activity proved to be a valuable instructional tool for improving the quality of mathematics instruction in a 7th grade classroom (Cho, 2012).

Sexton (2012) postulates that curriculum reforms in the teaching of mathematics have changed from memorization of facts to deeper levels of understanding. Sexton (2012) agrees with Cho (2011) in that teaching mathematic should be fun with the help of cartoons. Sexton's (2012) study reports an aspect of a small-scale pilot study that sought to illuminate the beliefs that students hold about their preferred mathematics learning environments. Although it was predicted that without any help from other materials, teaching and learning mathematics would be boring for the students. Sexton (2012) also highlights the role that 'concept cartoons' played in making known these beliefs of different learning environments. The results revealed that students preferred concept cartoons in their learning environment. Toh (2012) argues that literature abounds in using cartoons, instead of the usual textbooks, to teach students reading. However, little study has been undertaken on using cartoons and comics to teach mathematics. Sexton (2012) and Cho (2011) disagree with Toh (2012) and stated that the use of cartoons in teaching and learning mathematics have been used, but not widely among students. Toh (2012) adds that it has always been a challenge for secondary school teachers to teach algebra, particularly for underachieving students. In this note, Toh (2012) proposes the use of cartoons and comics, which are usually enjoyed by school-going children, in teaching algebra. Feedback from teachers revealed that their 
students became highly motivated to learn the subject by using cartoons and comics in algebra lessons. The teachers were able to engage their students in the process of learning elementary algebra.

VanWyk's (2011) study claims that excellent and effective teaching demands a host of devices, techniques and strategies, not only to achieve cross critical outcomes, but because variety is a desideratum. One teaching instrument, which perhaps is too seldom used, is the economics cartoon (VanWyk, 2011). To encourage this development, learning activities become important. VanWyk (2011) investigates as to why economics students' didactics prescribed cartoons as a teaching tool in order to enhance their learning. A survey was conducted to determine the use of cartoons as an effective teaching tool in economics education. The results of the study by VanWyk (2011) in confirmatory factor analyses indicated that the six-factor-model shows a reasonable fit, since the two out of the three conditions were consistently satisfied for the six-factor-model of this study. Further, the results of the interviews revealed that cartoons positively enhanced constructive learning, cooperative learning and collaborative learning amongst peers. Moreover, suggestions were made on how to use cartoons as a technique for creating interest as well as for developing critical thinking and reflective teaching skills in economics education. Hence, cartoons have been widely used among educators, particularly to enhance learning in the fields of Science (Ross, 2009), Mathematics (Toh, 2012; Cho, 2012; Tim, 2010; Sexton, 2006), Economics (VanWyk, 2011), Science and technology (Balim et al, 2008), Children psychology development (Valdivieso \& Lopez, 2012), and English (Arikan \& Taraf, 2010; Tanner \& Green, 2002; Bishop \& Cates, 2001).

Based on the research and literature above, it can be seen that there were lack of studies on television cartoon, particularly on Malay cartoons. Therefore, the objectives of the study were to identify and discuss the characters, storyline and moral values in Malay cartoons.

\section{Methodology}

The samples involved in the study were ten subjects from a Malay language proficiency class at one of the universities in Korea. The subjects viewed 8 episodes of Upin and Ipin for 1 hour a week for a total of 8 weeks. Upin and Ipin is a cartoon series that is famous in Malaysia. The language used in the cartoon is Malay. After viewing the cartoon, the subjects were interviewed based on their views about the cartoon. The subjects had to identify and discuss the characters, storyline and moral values in the cartoon. The subjects' interactions were selected based on the purpose of the study. They were named S1, S2, S3, S4, S5, S6, S7, S8, S9 and S10 (Student 1, Student 2, Student 3, Student 4, Student 5, Student 6, Student 7, Student 8, Student 9 and Student 10). The interactions from all of the subjects were analyzed by using the discourse analysis method by Brown and Yule (1983).

\section{Results and Discussion}

\subsection{Characters in Upin and Ipin}

There are 20 characters in Upin and Ipin. The main characters are Upin and Ipin (Twins- Upin the older sister and Ipin the younger brother), Kak Ros (Sister) and Opah (Grandmother). Upin and Ipin live with their sister and grandmother at Kampung Durian Runtuh. Upin and Ipin's parents died when they were young. Kak Ros is the eldest sister, who is a caring and loving person. She sometimes teases the twins and plays with them. Opah is a loving person and loves the three grandchildren.

Based on the above main characters, all of the subjects seemed to recognize the characters. The subjects stated that all the characters were different and therefore, it was easier to understand the story. After eight weeks of watching Upin and Ipin, all the subjects provided their views on the main characters.

Table 1 bellow showed the subjects' opinions on the main characters in Upin and Ipin. The subjects provided comments after eight weeks of viewings. As for Upin, S1, S6, S7, S8 and S9 stated that Upin helped Ipin with either housework or by teaching Ipin with the computer. Since Upin was clever with the computer, she taught Ipin in using it. Moreover, the subjects stated that Upin loves the computer and therefore, she spent most of the time trying out new programs from the computer. Further, S2 and S3 stated that Upin was always playing pranks with Ipin. Upin would love to tease Ipin since they were always together. Upin seemed to be happy being together with Ipin, but at times, she tried to joke with him. S4 and S10 stated that Upin loved to chat with Opah. The subjects stated that since Upin was a girl, she seemed to want to have a girl talk with Opah. The subjects also stated that Upin felt comfortable to be sitting near Opah when Opah was busy with her housework.

Ipin's character was different from Upin. Although they were twins, Ipin was funnier than Upin. S5, S7, S9 and S10 stated that Ipin was a funny boy. He makes everyone laugh with his character. The subjects stated that Ipin was enjoying himself all the time and at times, he makes funny jokes. The subjects seemed to love his funny character. S1, S4 and S5 stated that Ipin was always in trouble. This showed that Ipin has been trying to get Upin 
and Kak Ros's attention. Ipin was trying to play around with them and as a result, he was naughty towards them. S1 stated that Upin has helped Ipin when he was in trouble. Besides being naughty, Ipin was a lovable boy. S2, S3 and S8 stated that Ipin looked innocent when he was fooled, and he also loved to say the famous line 'boleh, boleh, boleh' (can, can, can). The subjects stated that the words showed that he was positive with everything that he did and thus, he would give positive attitudes toward others. S6 stated that Ipin loved fried chicken since most of the episodes showed that Ipin loved fried chicken. The subject stated that Ipin was really cute when he asked Kak Ros for fried chicken .

Table 1. Summary of the main characters in Upin and Ipin by the 10 subjects

\begin{tabular}{|c|c|c|c|c|}
\hline & Upin & Ipin & Kak Ros & Opah \\
\hline $\mathrm{S} 1$ & $\begin{array}{l}\text { She helps Ipin all } \\
\text { the time. }\end{array}$ & $\begin{array}{l}\text { He always gets in trouble } \\
\text { and Upin helps him. }\end{array}$ & $\begin{array}{l}\text { Always there for the } \\
\text { twins. }\end{array}$ & $\begin{array}{l}\text { Loving the three } \\
\text { grandchildren. }\end{array}$ \\
\hline S2 & $\begin{array}{l}\text { She plays pranks } \\
\text { with Ipin. }\end{array}$ & $\begin{array}{l}\text { Being innocent with the } \\
\text { prank. }\end{array}$ & $\begin{array}{l}\text { Teases the twins all } \\
\text { the time. }\end{array}$ & $\begin{array}{l}\text { Busy cooking and tidying } \\
\text { up the house. }\end{array}$ \\
\hline $\mathrm{S} 3$ & $\begin{array}{l}\text { She is always } \\
\text { together with Ipin. }\end{array}$ & $\begin{array}{l}\text { He loves to say 'boleh, } \\
\text { boleh, boleh' (can, can, can). }\end{array}$ & $\begin{array}{l}\text { Always gives advice } \\
\text { to the twins to help in } \\
\text { the house. }\end{array}$ & $\begin{array}{l}\text { Teaches the twins to do } \\
\text { house chores. }\end{array}$ \\
\hline S4 & $\begin{array}{l}\text { She loves to chat } \\
\text { with Opah. }\end{array}$ & $\begin{array}{l}\text { He is naughty toward Upin } \\
\text { and Kak Ros. }\end{array}$ & $\begin{array}{l}\text { Gets angry with the } \\
\text { twins when they did } \\
\text { not help in the house. }\end{array}$ & $\begin{array}{l}\text { Advises the } \\
\text { grandchildren about } \\
\text { respect toward elders. }\end{array}$ \\
\hline S5 & $\begin{array}{l}\text { She is good with } \\
\text { the computer. }\end{array}$ & He is funny. & Teases the twins. & $\begin{array}{l}\text { Teaches the twins about } \\
\text { moral values. }\end{array}$ \\
\hline S6 & $\begin{array}{l}\text { She teaches Ipin } \\
\text { with the computer. }\end{array}$ & He loves fried chicken. & $\begin{array}{l}\text { Advises the twins } \\
\text { about moral values. }\end{array}$ & $\begin{array}{l}\text { Cooks for the whole } \\
\text { house. }\end{array}$ \\
\hline S7 & She is clever. & He is very funny. & $\begin{array}{l}\text { Always there for the } \\
\text { twins. }\end{array}$ & $\begin{array}{l}\text { Tells moral stories to the } \\
\text { grandchildren. }\end{array}$ \\
\hline S8 & She teaches Ipin. & $\begin{array}{l}\text { He loves to say, 'boleh, } \\
\text { boleh, boleh' (can, can, can). }\end{array}$ & $\begin{array}{l}\text { Gives advice to the } \\
\text { twins. }\end{array}$ & $\begin{array}{l}\text { Advises the twins about } \\
\text { moral values. }\end{array}$ \\
\hline S9 & $\begin{array}{l}\text { She helps Ipin all } \\
\text { the time. }\end{array}$ & Ipin is funny. & Teases the twins. & $\begin{array}{l}\text { Busy with housework for } \\
\text { the family. }\end{array}$ \\
\hline $\mathrm{S} 10$ & $\begin{array}{l}\text { She loves to chat } \\
\text { with Opah. }\end{array}$ & He is funny. & $\begin{array}{l}\text { Teaches the twins } \\
\text { about housework. }\end{array}$ & $\begin{array}{l}\text { Teaches the twins to } \\
\text { respect others. }\end{array}$ \\
\hline
\end{tabular}

Kak Ros's character was also a main attraction since she was always there for the twins. S2, S5 and S9 stated that Kak Ros teased the twins when they were in the house. The subjects stated that Kak Ros did that because she loved the twins and wanted to play with them once in a while. S1 and S7 stated that Kak Ros was always there for the twins. The subjects stated that Kak Ros loves the twins and she pitied the twins for losing their parents at an early age. Hence, Kak Ros was always giving advice to the twins. This was true when S3, S6 and S8 stated that Kak Ros was always giving advice to the twins. The subjects stated that Kak Ros gave advice in a very polite manner such that the twins could accept it. It was sensible for Kak Ros to do that for the two very young twins. Although Kak Ros loves the twins, at times, she was angry with them. This was stated by S4; Kak Ros was angry with the twins since they always made a mess in the house. However, the subject stated that Kak Ros was angry for only a short period of time because the twins helped her with cleaning. S10 stated that Kak Ros helped the twins with their homework. The subject also stated that Kak Ros has been helping the twins after dinner with the homework and made sure that the twins did the work until it was done.

Opah has been the lovable character in Upin and Ipin. S1 and S6 stated that Opah was a lovable person and it showed in the story. Opah's gestures and face had shown that she loved all the grandchildren very much. S3, S5, S10 stated that Opah taught moral values to the grandchildren. The subjects stated that Opah taught the children 
by showing examples of good moral values. For example, helping each other in the house and finishing the chores given to them. The grandchildren seemed to be listening to Opah. Hence, S4, S7, S8, and S10 stated that Opah has also been giving advice to the grandchildren, particularly to Upin and Ipin. The subjects stated that the advices were based on moral values including respect towards one other. The comments were nearly the same with S3, S5 and S10, where the subjects stated that Opah taught moral values to the grandchildren. The subjects also stated that the advice given by Opah has been repeated to ensure that the twins understood the meaning of respect towards others. This showed that Opah, as an elderly, was concerned with Upin and Ipin. Furthermore, S2 and S9 stated that Opah were always busy cooking and doing housework. The subjects stated that since Opah stayed home, she cooked and did housework for the grandchildren. Overall, Opah was seen as being happy with the grandchildren.

All the subjects managed to give comments about the main characters in Upin and Ipin. It seemed that the comments were true since the characters that they mentioned were described correctly. All the subjects seemed to be excited when describing the characters because they have watched the cartoon for eight weeks. They stated that they loved the cartoon characters because the twins were cute, joyful and playful, which made the story even better.

\subsection{Storyline in Upin and Ipin}

The selected episodes for the study were viewed and summarized by the subjects. The episodes involved were summarized according to the original script as follows.

Episode 1: Upin and Ipin were five years old and knew the meaning of fasting and the reason they had to fast. Opah and Kak Ros explained to them and it was the first time that both twins started to fast.

Episode 2: It was difficult for both Upin and Ipin to fast. They tend to forget and woke up early in the morning and played in the afternoon. They were tired by the end of the day. Kak Ros and Opah advised them occasionally.

Episode 3: The breaking of fasting with the twins. They managed to finish the day while having fun with Kak Ros and Opah. After breaking fasting, they ate and fell asleep.

Episode 4: Upin and Ipin followed Opah and Kak Ros to pray. Upin and Ipin listened to the advice from Opah and Kak Ros.

Episode 5: Opah advised Upin and Ipin about being patient. It was eid and Upin and Ipin had guests in the house. They shared food and Opah always gave advice about moral values to them.

Episode 6: Kak Ros taught Upin and Ipin not to waste food and money when they could not finish eating. Upin showed his skill with the computer to Ipin.

Episode 7: Opah advised Upin and Ipin to work hard and perform chores. Opah advised them to respect others. Upin and Ipin played together and Kak Ros teased them.

Episode 8: Kak Ros made new outfits for the twins. The twins were happy. Opah was happy with the unity and love present among the grandchildren.

Table 2. Summary of Upin and Ipin Storyline indicated by subjects

\begin{tabular}{ll}
\hline & Storyline \\
\hline S1 & The story was about togetherness, family, loving and caring. \\
S2 & The loving family. Everybody loves Upin and Ipin. \\
S3 & Funny stories with moral values. \\
S4 & About family and love. \\
S5 & About Upin and Ipin and teaching moral values. \\
S6 & Really funny stories with moral values. \\
S7 & Loving family and funny. \\
S8 & Clever twins, funny and interesting. \\
S9 & Everybody loves the twins and the family. \\
S10 & Loving and caring family. \\
\hline
\end{tabular}


All the subjects managed to provide the correct summary of the storyline for each episode. The summary from the original script can be referred above. All of the subjects stated that the storyline for all eight episodes were about family values, love, and care. This was clearly shown when the stories were focused on Upin and Ipin, Kak Ros and Opah. The subjects loved the storyline since they would be able to imagine the twins in the family. S3, S6, S7 and S8 stated that the episodes were funny. The subjects had so much fun watching the funny characters of Upin and Ipin. The story lines were easy to understand and even the jokes were understandable. The subjects understood the jokes when they heard it for the first time. This showed that the scripts for Upin and Ipin were meant to be for children, and the language used were understandable. The subjects uttered that the jokes were funny and suitable for Upin and Ipin. They also stated that Kak Ros and Opah were funny, although Opah, at times, was trying to give advice to Kak Ros, Upin and Ipin. S8 added that the twins were clever in the story. The subjects stated that the storyline showed that the twins were able to solve the difficult questions from Kak Ros and Opah. The subjects also stated that the story showed Upin trying to use the computer, and also taught Ipin and Kak Ros. The story about the cleverness of Upin was shown occasionally; although Ipin was funny at times, the story showed that Ipin was clever dealing with the problems that they had during the fasting month.

S2, S5, S8, and S9 stated that the storylines concentrated more on Upin and Ipin. The storylines were about the activities of Upin and Ipin during the fasting month. Also, the subjects stated that the storylines were based on the twins playing games during the day and how they became exhausted in the afternoon and evening. The subjects mentioned that the story focused on Upin and Ipin jumping up and down inside the house since they did not want to play outside. Also, there was a story about Upin and Ipin following Kak Ros and Opah to the market in order to buy some food. The subjects stated that Upin and Ipin were small boys who wanted to have everything and wanted to eat everything; but at the end, they wasted all of the food. The storyline showed the moral values in being sensible about making choices. S3, S4, S5, S6 and S10 stated that each episode consisted of moral values. This showed that the moral values of making sensible choices would be appropriate for the twins. The subjects also stated that the moral values in the episodes were about being respectful, caring and helping one another. The subjects mentioned that they understood the moral values in the episodes and they were able to relate to the moral values with the storyline for each episode. Thus, S1 was happy to say that the storylines in Upin and Ipin consisted of unity in a family, loving each other unconditionally and caring for each other at all times. Subject 1 seemed to understand the story about the family; he showed that he was content with the message in the stories.

\subsection{Moral values in Upin and Ipin}

There were moral values for each episode in Upin and Ipin. The moral values were inserted in the script so that the viewers would understand the story even better. Thus, the moral values were repeated in the episode in order to clearly deliver the message. The moral values, according to all the subjects, were listed as follows.

Table 3. Summary of Moral Values in Upin and Ipin indicated by subjects

\begin{tabular}{lcccccc}
\hline & loving & caring & respect & helping each other & hardworking & sensible \\
\hline S1 & $/$ & $/$ & & $/$ & $/$ & \\
S2 & $/$ & $/$ & $/$ & $/$ & $/$ & \\
S3 & $/$ & & $/$ & $/$ & $/$ & $/$ \\
S4 & $/$ & & $/$ & $/$ & & $/$ \\
S5 & $/$ & $/$ & $/$ & $/$ & $/$ & $/$ \\
S6 & $/$ & $/$ & $/$ & $/$ & $/$ & $/$ \\
S7 & $/$ & $/$ & $/$ & $/$ & $/$ & $/$ \\
S8 & $/$ & & $/$ & $/$ & $/$ & $/$ \\
S9 & $/$ & & $/$ & $/$ & $/$ & \\
S10 & $/$ & $/$ & $/$ & & $/$ & \\
\hline
\end{tabular}

Table 3 above stated the summary of moral values in Upin and Ipin by all ten subjects. The subjects uttered individual words in order to explain the moral values included in the episodes that they viewed. All of the 
subjects stated that values of 'love' and 'helping' each other in the episodes. The subjects mentioned that the moral values were mostly in all the episodes. The subjects uttered that the values were mentioned by all the main characters, particularly by Opah and Kak Ros, who tried to give advice to Upin and Ipin. 'Love' and 'helping' each other moral values were understood by all the subjects since the words were uttered in the scripts. Furthermore, S1, S2, S3, S4, S7, S8, S9 and S10 stated that the moral value 'hardworking' was also in the episodes. The subjects mentioned that Opah and Kak Ros were always reminding Upin and Ipin to become 'hardworking'. The subjects also uttered that Upin and Ipin were 'hardworking' after being reminded by Opah and Kak Ros; the twins were seen sharing the moral values with their friends at school.

S1, S2, S5, S6, S7 and S10 stated that there was another moral value in Upin and Ipin, 'caring'. The subjects uttered that this moral value was clearly shown in all the episodes. The subjects mentioned that Opah and Kak Ros had showed that they 'care' about Upin and Ipin. According to the subjects, Opah and Kak Ros also mentioned the word 'care' with the twins and advised them about the moral value 'care' towards family members, friends, teachers, animals and the environment. Moreover, S2, S3, S4, S5, S6, S7, S8, S9 and S10 stated that there was another moral value 'respect' in Upin and Ipin. The subjects stated that the moral value 'respect' was clearly identified in the script where Opah and Kak Ros have been reminding Upin and Ipin to be respectful towards others. The subjects stated that Opah and Kak Ros also reminded Upin and Ipin to be respectful towards people, who were older than them, including the elderly, family member, teachers, friends and everyone around them. The subjects mentioned that Upin and Ipin understood the moral value since they tried to be respectful toward their teacher and friends at school.

S4, S5, S6, S8 and S10 stated that there was another moral value in Upin and Ipin, 'sensible'. However, this moral value was not stated in the script of Upin and Ipin; yet, the storyline has shown that the characters have played the role of being 'sensible'. The subjects stated that Upin and Ipin were being 'sensible' when they were behaving well in front of an elderly who passed by. They were also seen walking nicely so that they did not accidently step on the shoes of the elderly. The subjects stated that the acting had shown the moral value and was understood by them. Moreover, the subjects stated that Upin and Ipin had played the major role in being 'sensible' the right way. They stated that Opah and Kak Ros were praising them for being 'sensible' in several episodes. For example, they were shown to be 'sensible' when they cleaned up after lunch and dinner, tidying up the bed and helping Opah and Kak Ros with other chores. The moral value had given the subjects the clue of being 'sensible' in their everyday lives.

To sum up, based on the results and discussion regarding the characters in Upin and Ipin, the storylines in Upin and Ipin and the moral values in Upin and Ipin, it can be revealed that all of the ten subjects understood the story. The results also revealed that the subjects were able to interact and communicate about the content of the story in the cartoon. It can be stated that the subjects found that the cartoon had triggered them in giving their opinions and views pertaining to the cartoon. The subjects were also able to identify the characters, storyline and moral values in the cartoon. Further, the subjects had gained confidence in giving their views as they were able to understand all the episodes in the cartoon. The results of the study were parallel to the study by Cho (2012); when cartoon activities have appropriate levels of difficulty and are clearly understandable, students' intrinsic motivation and interest increased, whereas learning anxiety decreased. Learning a second language has been difficult for the learner, and hence, cartoon activities have helped them in the process of learning.

\section{Conclusion}

The author concludes that the study implicates educators in considering cartoon for teaching a second language. Although cartoons are not new among learners, cartoons consisting of moral values that reflect the culture and attitude of a person would help in the process of learning. Educators will have to choose the most appropriate materials in the form of cartoons in order to enhance students learning a second language. Educators must also consider and select cartoons that are appropriate for learning since most cartoons in the media were for fun without adapting moral values into them. It is recommended that future research will concentrate on cartoons with moral values for enhancing Malay language writing skills.

\section{References}

Arikan, A., \& Taraf, H. U. (2010). Contextualizing young learners' English lessons with cartoons: Focus on grammar and vocabulary. Procedia Social and Behavioral Sciences, 2, 5212-5215. http://dx.doi.org/ 10.1016/j.sbspro.2010.03.848

Balim, A., Inel, D., Evrekli, E., \& Kesertcioglu, T. (2008). The Use of Concept Cartoons in Constructive Science and Technology Education: The Examples about the Subject of Pressure. XIII.IOSTE Symposium, The Use of Science and Technology Education for Peace and Sustainable Development. September 21-26, 2008, 
Kuşadası / Turkey, 1-7

Bishop, M. J., \& Cates, W. M. (2001). Theoretical foundations for sound's use in multimedia instruction to enhance learning. Educational Technology Research and Development, 49(3), 5-22. http://dx.doi.org/ $10.1007 / \mathrm{BF} 02504912$

Cho, H. Y. (2012) The Use of Cartoons as Teaching a Tool in Middle School Mathematics Ph.D., Columbia University. Retrieved September 3, 2012 from http://academiccommons.columbia.edu/catalog/ac\%3A 149393

Cleaver, S. (2008). Comics and graphic novels. Instructor, 117(6), 28-30.

Harmer, J. (1992). The Practice of English Language Teaching. U.Uk: Longman

Hedge, T. (2002). Teaching and Learning in the Language Classroom. China: Oxford University Press.

Keogh, B., \& Naylor, S. (1999). Concept cartoons, teaching and learning in science: An evaluation. International Journal of Science Education, 21, 431-446. http://dx.doi.org/10.1080/095006999290642

Kinchin, I. M. (2004). Investigating students' beliefs about their preferred role as learners. Educational Research, 46(3), 301-312. http://dx.doi.org/10.1080/001318804200277359

Normaliza Abd Rahim dan Siti Nur Aliaa Roslan. (2012) Kata Kerja Melalui Penerapan Kinestetik Pelajar Sekolah Rendah di Nottingham United Kingdom: Satu Analisis. Jurnal Bahasa Brunei. JB 26, Mei - Ogos, 96-104

Nunan, D. (1999). Second language teaching and learning. Boston, Massachusetts: Heinle \& Heinle.

Rahim, N. A. (2011) Music Video Clip Storyboard Writing among Focus Group Learners of Media. Global Media Journal Malaysia, 1(1), 78-91.

Rahim, N. A., \& Harun, N. I. (2011). Emotions among the Primary School Students: A Malay Drama Program (Software). UPENA Johor, 10,185-198.

Ross, P. M. (2009). The use of cartoons in teaching and learning invertebrate biology. University of Western Sydney. Retrieved September 3, 2012, from http://www.bioassess.edu.au/examples/ross-use-cartoonsteaching-and-learning-invertebrate-biology

Sexton, M. (2012) Using Concept Cartoons to Access Student Beliefs about Preferred Approaches to Mathematics Learning and Teaching. Australian Catholic University, Retrieved September 3, 2012, from http://www.merga.net.au/documents/MERGA33_Sexton.pdf

Tanner, R., \& Green, C. (1998). Task for Teacher Education. Malaysia: Addison Wesley Longman.

Tilley, C. L. (2008). Reading comics. School Library Media Activities Monthly, 24(9), 23-26.

Toh, T. L. (2012). Use of Cartoons and Comic to Teach Algebra in Mathematics Classrooms. Retrieved September 3, 2012, http://www.mav.vic.edu.au/files/conferences/2009/12Toh.pdf

Urbani, T. (1978). Fun, funny, funnies. Teacher, 96(1), 60-68.

Valdevieso, A. A., \& Lopez, J. P. (2012). Research for Children's Learning: The Impact of Cartoons on Children's Psychological Development. Retrieved September 3, 2012, from http://library.iated.org/view/ ALONSOVALDIVIESO2011RES

VanWyk, M. (2011). The Use of Cartoons as a Teaching Tool to Enhance Student Learning in Economics Education. $J$ Soc Sci, 26(2), 117-130.

Wright, G., \& Sherman, R. B. (2006). Comics redux. Reading Improvement, 43(4), 165-172.

Ying, L. Z. (2010). Learning Communication Skills by Making Cartoon Films. Proceedings of the European Conference on Games Based Learning, 487-493.

\section{Copyrights}

Copyright for this article is retained by the author(s), with first publication rights granted to the journal.

This is an open-access article distributed under the terms and conditions of the Creative Commons Attribution license (http://creativecommons.org/licenses/by/3.0/). 